\title{
Problem Aspects of the Implementation of Legislation on Social Protection of Persons with Disabilities in the Russian Federation
}

\author{
${ }^{1}$ Julia N. Avdonina, ${ }^{2}$ Gulnara M. Khamitova \\ ${ }^{1}$ Kazan Federal University \\ ${ }^{2}$ Kazan State Medical University \\ Email: gulnarakgmu@mail.ru,kkafedra983@gmail.com
}

\author{
Received: 02 ${ }^{\text {nd }}$ November 2018, Accepted: $28^{\text {th }}$ November 2018, Published: $3^{\text {st }}$ December 2018
}

\begin{abstract}
This article raises issues and addresses the problems of strengthening the integrity of the social security system and the social protection of disabled people on the basis of socio-economic, financial, economic and organizationaltechnical unity. This largely depends on the rationality of management of this industry. The theme of the implementation of legislation on social protection of disabled people is relevant in our time, as social assistance and assistance to disabled people in modern Russian society is not at the proper level. Disability is not only a problem of the individual, but also of the country and society as a whole. This category of people is in dire need not only of social protection, but also in understanding the problems of strangers. These difficulties lie not only in pity, but also in human sympathy and equal treatment of them as citizens. In order to help people with disabilities in the country formed a program of social protection of persons with disabilities, laws, various international documents - agreements, acts, declarations. As a result, the quality of life of persons with disabilities is increasing day by day, and obstacles to the achievement of the benefits that are available to citizens who do not have significant health damage are removed.
\end{abstract}

\section{Keywords}

Disability, Categories of Disabilities, Social Protection, Limitation of Activity, Social Security, Social Legislation.

\section{Introduction}

The largest number of people with disabilities are disabled people of working age.

Modern Russian legislation in terms of social assistance to people with disabilities is gradually approaching the laws and principles that are established in the world community. Consider the problems that people with disabilities have in the implementation of those benefits that are guaranteed by the government and are enshrined in current legislation.

\section{Methods}

To achieve this objective, the research applied general scientific methods of cognition: the method of analysis, the system method, the method of comparison, the method of generalization.

\section{Results and Discussion}

In Russia, the rules for improving the environment around the people with disabilities, taking into account their needs, are laid down in the Decree of the Government of the Russian Federation of August 12, 1994 № 927 “On Ensuring the Formation of an Accessible Living Environment for People with Disabilities".

In accordance with this regulation, the standards and requirements that meet the needs of persons with disabilities have been developed, for example, when building housing or arranging social infrastructure. However, the most difficult moment is still the lack of a developed effective mechanism that allows implementing these standards and requirements. Also, the Federal Target-Oriented Program, adopted by Decree of the President of the Russian Federation of October 2, 1992 №1156 “On Measures to Create an Accessible Living Environment for Disabled Persons", was formed and is being implemented.

The formation of an accessible environment should begin with the meticulous development of all the smallest elements of this structure. This will be the key to the further implementation of all the declared measures, where due attention will also be paid to the housing needs of people with disabilities and social infrastructure.

The Federal Law of November 24, 1995 № 181- FL “On the Social Protection of Disabled Persons in the Russian Federation" states that the authorities must create conditions for the disabled to have free access to social infrastructure facilities.

Thus, although the Decree of the President of the Russian Federation of October 2, 1992 № 1156 “On Measures for the Formation of an Accessible Living Environment for Persons with Disabilities" was signed several years ago, it can be stated that at the moment the grounds for the formation of the living environment of persons with disabilities in which there are would no barriers just starting to be developed. The main hinders to the implementation of the adopted urban and housing norms and standards are often financial problems.

Let us turn to the problems in medical care. In accordance with the Federal Law of November 21, 2011 №323-FL "On the Basis of Protecting the Health of Citizens in the Russian Federation" in case of illness, disability and in other cases, citizens have the right to medical and social care, including preventive, therapeutic and diagnostic rehabilitation, prosthetic and orthopedic and denture care. 
Based on the norms of the existing legislation of the Russian Federation, the Ministry of Health of the Russian Federation and its territorial subdivisions in the regions guarantee the provision of free medical care, medical care on preferential terms, and the provision of medicines to people with disabilities. Treatment of disabled persons, as well as the necessary inpatient care, must be carried out at the expense of compulsory medical insurance.

One type of medical care - sanatorium-and-spa treatment is also guaranteed for disabled people in the Russian Federation free of charge. According to their individual rehabilitation programs, disabled people and children with disabilities are provided with facilities in sanatoria and health resorts in an extraordinary or priority order. The procedure for obtaining a place in a sanatorium begins with the registration of one who is in need of such treatment. The persons with disabilities do this in the territorial body of social protection domiciliary, submitting the appropriate statement, that confirms the referral of medical specialist. However, not all is so easy. Waiting for a voucher by disabled people to a sanatorium has often been temporized for several years.

In accordance with Article 40 of the Constitution of the Russian Federation, citizens have the right to free housing improvement. To this law, secured at the expense of the budget, certain categories of citizens listed in the legislation have the right. Among them are the citizens of scanty means and who are hard up and those who find themselves in a difficult life situation and so on. Other categories are provided with housing at an affordable cost - for example, disabled war veterans and people suffering from severe forms of certain chronic diseases.

One of the main problems in the training and education of people with disabilities is that there are no special, correctional training programs developed in accordance with their diagnoses. Training places for people with disabilities are still insufficiently equipped. In this regard, they find themselves in unequal conditions when studying with ordinary students in general education institutions. According to the Constitution of the Russian Federation, every citizen in our country has the right to work. Without a doubt, this right is guaranteed to the disabled people. It is established by the Federal Law of November 24, 1995 №181-FL “On Social Protection of Disabled Persons in the Russian Federation” and by the Law of the Russian Federation of April 19, 1991 № 1032-1 "On Employment of the Population in Russia". These regulations are intended not only to provide an opportunity for people with disabilities to realize themselves as integrated members of society, entering into employer-employee relations, but also to provide themselves financially, including doing business. It is very important not only to declare these opportunities but also to develop a working mechanism allowing to implement the provisions of the law in the real life of people with disabilities. At present, the employment of citizens with disabilities in the Russian Federation is at a catastrophically low level, regional programs to promote their employment do not have any tangible progress.

One cannot but agree with the statement that only quotas for jobs for people with disabilities, established by the relevant territorial authorities at the level of the subjects of the federation, will be able to get the deadlock for solving this problem. And most importantly, this measure should apply to all subjects of labor relations without exception, regardless of the form of ownership.

These measures can be implemented within the framework of the Law of the Russian Federation dated April 19, 1991 № 1032-1 “On Employment of the Population in the Russian Federation”.

However, quoting is not so simple. Formally, employers comply with the requirements of the law, allocate a certain number of jobs for the work of people with disabilities. But in practice, it often turns out that these jobs do not meet the requirements of persons with disabilities. And the legislator did not clearly define the criterion of compliance

Social protection of disabled persons includes an important mechanism, such as rehabilitation. Rehabilitation of persons with disabilities with their subsequent employment is economically beneficial to the state, since the funds invested in it will be returned in the form of tax revenues

The Federal Law of December 28, 2013 № 442-FL“'On the Basics of Social Services for Citizens in the Russian Federation" defines social services as the activity of certain services for social support, the provision of social, medical, psychological, pedagogical, legal services, services in order to increase the communicative potential of recipients of social services, social-labor and urgent social services. Also for the social adaptation and rehabilitation of people in difficult life situations. It is also necessary to mention the Resolution of the Government of the Russian Federation of November 25, 1995 № 1151 “On the Federal List of State-Guaranteed Social Services Provided to Elderly Citizens and Persons with Disabilities by State and Municipal Social Service Institutions". This act lists the services that are provided to the disabled and the elderly in inpatient and in-home conditions, such as material, social, medical, legal, ritual, educational services, and the services related to social and labor rehabilitation.

\section{Summary}

Based on the foregoing, we can draw the following conclusions:

1. It is important to fix a fundamentally different approach to the adoption of program legislation in the field of social protection of persons with disabilities. Their adoption must necessarily be related to the real economic possibilities of state bodies to realize their full position.

2. The systems of social security and social protection of persons with disabilities should be combined, to represent the socio-economic and organizational and technical integrity.

3. It is necessary to make timely amendments to the regulations on the social protection of persons with disabilities, to quickly supplement them, excluding irrelevant legislation, as well as those that are not financially supported.

4. An effective mechanism for continuous improvement of the living standards of people with disabilities acting as a permanent corrector of guaranteed minimum standards and benefits for people with disabilities should be formed. At 
the same time, an increase in the list of benefits and services should primarily concern those persons with disabilities who are least advanced, have a greater degree of disability or functional impairment of the body.

5. To shorten expense items associated with spending on public policy, extend funding for training, etc., especially paying great attention to rehabilitation measures.

6. It is necessary to ensure guaranteed addressing of their needs in the area of rehabilitation work.

7. To set the stage for work on the training of specialists for the rehabilitation of disabled people.

8. To modernize and accelerate the dynamics of the formation of the rehabilitation industry as the most important pivot of the social protection of persons with disabilities.

9. The government should help in the fastest implementation of the program on the living environment of persons with disabilities.

10. It must be remembered that the needs of people with disabilities living in rural areas should also be reflected in existing regulations.

\section{Conclusion}

In order to render social services for people with disabilities according to the established rules, the problem of an accessible environment requires an immediate solution. It is very important to draw the interest of the public, authorities and journalists to it by all means.

\section{Acknowledgments}

The work is performed according to the Russian Government Program of Competitive Growth of Kazan Federal University.

\section{References}

1. Antipieva N.V. Social Protection of Persons with Disabilities in the Russian Federation [Electronic Resource]: Legal Regulation / N.V. Antipieva. Access Mode: http://law.edu.ru (Access Date: November 09, 2017)

2. Law of the Russian Federation of April 19, 1991 № 1032-1 "On Employment of the Population in the Russian Federation" / Reference-legal system "Consultant Plus" [Electronic Resource]. Access mode: http://www.consultant.ru, free. (Access Date: November 03, 2017).

3. The Constitution of the Russian Federation" (adopted by popular vote on December 12, 1993) / Reference legal system "Consultant Plus" [Electronic Resource]. Access Mode: http://www.consultant.ru, free. (Access Date: November 03, 2017).

4. Decree of the Government of the Russian Federation of August 12, 1994 № 927 "On Ensuring the Formation of an Accessible Living Environment for People with Disabilities" / Reference and legal system "Consultant Plus" [Electronic Resource]. Access Mode: http://www.consultant.ru, free. (Access Date: November 03, 2017).

5. Decree of the Government of the Russian Federation of April 15, 2014 № 298 “On Approval of the State Program of the Russian Federation" Assistance to Employment of the Population "/ Reference and Legal System" Consultant Plus "[Electronic Resource]. Access Mode: http://www.consultant.ru, free. (Access Date: November 03, 2017).

6. Decree of the Government of the Russian Federation of November 25, 1995 №1151 "On the Federal List of StateGuaranteed Social Services Provided to Elderly Citizens and Disabled by State and Municipal Social Service Institutions" / Consultant Legal Reference System [Electronic Resource]. Access Mode: http://www.consultant.ru, free. (Access Date: November 03, 2017).

7. Romanov P.V., Yarskaya-Smirnova E.R. Disability Policy: Social Citizenship of Persons with Disabilities in Modern Russia. - M .: Dashkov and K, 2015 -P. 220.

8. "Labor Code of the Russian Federation" dated December 30, 2001 №197-FL/ Reference-Legal System "Consultant Plus" [Electronic Resource]. Access Mode: http://www.consultant.ru, free. (Access Date: November 03, 2017)

9. Territorial Body of the Federal State Statistics Service for the Republic of Tatarstan: Disability of the Population [Electronic Resource] / Access Mode: http://tatstat.gks.ru / (Access Date: November 08, 2017)

10. Decree of the President of the Russian Federation of October 2, 1992 № 1156 “On Measures for the Formation of an Accessible Living Environment for Persons with Disabilities" / Reference and Legal System "Consultant Plus" [Electronic Resource]. Access Mode: http://www.consultant.ru, free. (Access Date: November 03, 2017).

11. Federal Law of November 24, 1995 № 181-FL "On Social Protection of Disabled Persons in the Russian Federation" / Reference and Legal System "Consultant Plus" [Electronic Resource]. Access Mode: http://www.consultant.ru, free. (Access Date: November 03, 2017).

12. Federal Law of November 21, 2011 № 323-FL “On the Basis of the Protection of Public Health in the Russian Federation" / Reference and Legal System "Consultant Plus" [Electronic Resource]. Access Mode: http://www.consultant.ru, free. (Access Date: November 03, 2017).

13. Federal Law of December 14, 2015 № 359-Ф3 “On the Federal Budget” / Consultant Legal Reference System "Electronic Resource" [Electronic Resource]. Access Mode: http://www.consultant.ru, free. (Access Date: November 03, 2017).

14. Yarskaya-Smirnova, E. R., Naberushkina, E.K. Social Policy with Disabilities: Social Policy on Persons with Disabilities. - Peter: The Tutorial Publishing House, 2004. - P. 316 